NBER WORKING PAPER SERIES

FINANCIAL LITERACY AROUND THE WORLD: AN OVERVIEW

Annamaria Lusardi

Olivia S. Mitchell

Working Paper 17107

http://www.nber.org/papers/w17107

\author{
NATIONAL BUREAU OF ECONOMIC RESEARCH \\ 1050 Massachusetts Avenue \\ Cambridge, MA 02138 \\ June 2011
}

The research reported herein was conducted pursuant to a grant from Netspar. Additional support was provided by the Pension Research Council and Boettner Center at the Wharton School of the University of Pennsylvania. The authors thank participants at the December 2010 Financial Literacy around the World conference at Collegio Carlo Alberto, Turin, Italy for suggestions and comments. They also thank Audrey Brown for editorial support. Opinions and errors are solely those of the authors and not of the institutions with which the authors are affiliated. The views expressed herein are those of the authors and do not necessarily reflect the views of the National Bureau of Economic Research.

NBER working papers are circulated for discussion and comment purposes. They have not been peerreviewed or been subject to the review by the NBER Board of Directors that accompanies official NBER publications.

(C) 2011 by Annamaria Lusardi and Olivia S. Mitchell. All rights reserved. Short sections of text, not to exceed two paragraphs, may be quoted without explicit permission provided that full credit, including (C) notice, is given to the source. 
Financial Literacy around the World: An Overview

Annamaria Lusardi and Olivia S. Mitchell

NBER Working Paper No. 17107

June 2011

JEL No. D14,D91

\begin{abstract}
$\underline{\text { ABSTRACT }}$
In an increasingly risky and globalized marketplace, people must be able to make well-informed financial decisions. Yet new international research demonstrates that financial illiteracy is widespread when financial markets are well developed as in Germany, the Netherlands, Sweden, Japan, Italy, New Zealand, and the United States, or when they are changing rapidly as in Russia. Further, across these countries, we show that the older population believes itself well informed, even though it is actually less well informed than average. Other common patterns are also evident: women are less financially literate than men and are aware of this shortfall. More educated people are more informed, yet education is far from a perfect proxy for literacy. There are also ethnic/racial and regional differences: city-dwellers in Russia are better informed than their rural counterparts, while in the U.S., African Americans and Hispanics are relatively less financially literate than others. Moreover, the more financially knowledgeable are also those most likely to plan for retirement. In fact, answering one additional financial question correctly is associated with a 3-4 percentage point higher chance of planning for retirement in countries as diverse as Germany, the U.S., Japan, and Sweden; in the Netherlands, it boosts planning by 10 percentage points. Finally, using instrumental variables, we show that these estimates probably underestimate the effects of financial literacy on retirement planning. In sum, around the world, financial literacy is critical to retirement security.
\end{abstract}

\author{
Annamaria Lusardi \\ George Washington School of Business \\ 2201 G Street, NW \\ Washington, DC 20037 \\ and NBER \\ alusardi@gwu.edu \\ Olivia S. Mitchell \\ University of Pennsylvania \\ Wharton School \\ 3620 Locust Walk, St 3000 SH-DH \\ Philadelphia, PA 19104-6302 \\ and NBER \\ mitchelo@wharton.upenn.edu
}


Rising life expectancies and falling fertility rates are straining employer-sponsored pensions and Social Security systems around the world. In response, several countries have transformed their retirement schemes by remaking their traditional defined benefit (DB) pensions into individual-account defined contribution (DC) schemes. This transformation shifts many of the decisions about financing retirement away from institutions - firms and governments toward individuals, imposing on workers the responsibility to save, invest, and spend wisely over the lifecycle. In some ways, this transition has wrought change for the better. For instance, when the labor force is mobile, pensions must be portable - and DC plans are more flexible than conventional DB plans that discourage labor mobility. Yet DC flexibility also presents the possibility that individuals might not do the right thing: they can undersave, fail to invest wisely, and run out of money in old age due to longevity risk (Mitchell, 2011; Poterba et al. 2008). For this reason, the new financial era will impose a much heavier burden on workers and their households than in the past to become financially literate - to learn how to process economic information and make informed decisions about household finances.

In other work, we have shown that financial literacy is closely tied to retirement planning and retirement wealth accumulation (Lusardi and Mitchell, 2007a, 2008a, 2009, 2011; Behrman et al. 2010). Yet many people are often woefully unaware of basic economics and finance, shortfalls that may lead them to make serious and often irreversible mistakes. The majority of research on these topics to date has focused on the level and extent of financial illiteracy in the United States (Lusardi and Mitchell, 2007a, 2009, 2011). In this paper, we report on an international project on financial literacy patterns in other seven countries which, like the United States, have added the financial literacy questions originally designed for the U.S. Health and Retirement Study (HRS) to national surveys. In what follows, we discuss how to measure 
financial literacy, as well as the links between financial literacy and financial behavior. We also draw out key lessons and research questions that emerge from this international project on financial literacy around the world.

\section{Measuring financial literacy}

While it is important to assess how financially literate people are, in practice it is difficult to explore how people process economic information and make informed decisions about household finances. Perhaps because of this, relatively few researchers prior to 2000 incorporated financial literacy into theoretical models of saving and financial decision-making.

Our effort, in the context of designing financial literacy measures for the US HRS, was to measure financial literacy keeping in mind four key principles:

1) Simplicity. We aimed to measure basic financial concepts, akin to the notions of the rudimentary ABC’s for reading literacy.

2) Relevance. Questions had to relate to concepts pertinent to peoples' day-to-day financial decisions over the life cycle; moreover, they had to capture general rather than contextspecific ideas. ${ }^{1}$

3) Brevity. Few representative surveys can devote much time to financial literacy topics, so the number of questions had to be kept to a minimum in order to secure widespread adoption. 4) Capacity to differentiate. We needed questions that can differentiate between financial knowledge levels, so as to compare people in terms of their scores on a common set of questions.

\footnotetext{
${ }^{1}$ Relatedly, we sought a small number of questions that would be relevant across ethnic/cultural groups rather than focus on any specific market. For example questions focusing on the US mortgage market (Moore 2003) would be difficult to translate to an international context.
} 
Our questions were designed to be included in an experimental financial literacy module for the 2004 Health and Retirement Study. In doing so, we relied on economic models of saving and portfolio choice to identify three economic concepts that individuals should have some understanding of, if they are to use them when making financial decisions: i) interest compounding; ii) inflation; and iii) risk diversification. To keep these concepts simple in the context of telephone or face-to-face interviews, we did not require respondents to engage in complicated calculations; rather, we simply evaluated whether people could carry out elementary calculations related to these concepts. To this end, we designed three questions which have now become the benchmark by which a wide variety of analysts measure financial literacy:

1) Suppose you had $\$ 100$ in a savings account and the interest rate was $2 \%$ per year. After 5 years, how much do you think you would have in the account if you left the money to grow?

More than \$102

Exactly \$102

Less than $\$ 102$

Do not know

Refuse to answer

2) Imagine that the interest rate on your savings account was $1 \%$ per year and inflation was $2 \%$ per year. After 1 year, how much would you be able to buy with the money in this account?

More than today

Exactly the same

Less than today

Do not know

Refuse to answer

3) Please tell me whether this statement is true or false. "Buying a single company's stock usually provides a safer return than a stock mutual fund."

True

False

Do not know

Refuse to answer

The first question measures numeracy or the capacity to do a simple calculation related to compounding of interest rates. Of course complex interest compounding is also important, but we elected to focus instead on whether individuals could get the general idea of calculations 
relating to interest rates. Our second question measures understanding of inflation, again in the context of a simple financial decision. The third question gauges knowledge of risk diversification; it is a joint test of knowledge about "stocks” and “stock mutual funds," and of risk diversification, since the answer to this question depends on knowing what a stock is and that a mutual fund is composed of many stocks. In view of the fact that employees are increasingly asked to select their pension investment portfolios, it is important to ask questions related to risk diversification. ${ }^{2}$

It will also be noted that, when structuring these questions, we also specified the list of possible answers, to make it easier for people to simply select a preferred response. Moreover, respondents could indicate they did not know the answer or chose to refuse to answer, if they wished. This procedure prevented respondents from being forced to pick a numeric answer, and it also enables us to differentiate across different levels of financial knowledge.

After implementing these questions in the 2004 HRS module for a sample of over 1200 respondents age 50+ (Lusardi and Mitchell, 2011), they were then thoroughly tested in other datasets using respondents from different age groups and time periods, and using different data collection methods. For instance, they were added to wave 11 of the National Longitudinal Survey of Youth (NLSY) for 2007-08 covering respondents age 23-28 (Lusardi et al. 2010). These questions were also added to a module in the American Life Panel in 2008, an internetbased panel data set (Lusardi and Mitchell, 2007b). Finally, these questions were added to the 2009 Financial Capability Study (FINRA, 2010) which included both phone interviews with a representative sample of the U.S. population, and an internet survey of about 500 respondents in each state (Lusardi, 2010). Across the board, these variables do a good job of characterizing

\footnotetext{
${ }^{2}$ When the Enron Corporation filed for bankruptcy in 2004, it turned out that a large number of now-jobless employees had also invested their entire pension assets into their company's now-worthless stock. It is therefore of interest to assess whether employees have learned from that event.
} 
peoples’ levels of financial knowledge; moreover, they also strongly correlate with financial behaviors, as will be detailed later.

Other efforts to measure financial literacy. A few prior studies have sought to get at related concepts with different measures, though all have limitations. For instance the HRS 'core' had a handful of questions measuring numeracy (Lusardi and Mitchell, 2007a), and the same numeracy questions were asked (sometimes slightly modified) in the England Longitudinal Survey of Ageing (ELSA; Banks and Oldfield, 2007), and the Survey of Health Ageing, and Retirement in Europe (SHARE; Christelis et al. 2010). While numerical ability is no doubt important, particularly for younger persons, we believe that mature adults also need the ability to make sound financial decisions. Moreover, it may be difficult to enhance numeracy in the older adult population, whereas it may be easier to boost knowledge of a few financial concepts fundamental for making financial decisions. Hilgert et al. (2003) and Moore (2003) developed a rather lengthy set of questions and were stand-alone financial literacy surveys, rather than brief questions offered as part of a larger socioeconomic data collection effort. The National Council on Economic Education (NCEE, 2005) measured financial knowledge among children and adults, but that survey did not gather ancillary information to evaluate whether financial literacy affects behavior. In our view, short financial literacy modules are best included in national surveys (rather than fielding surveys on financial literacy only), because financial literacy responses can then be linked to other causes and effects. The OECD report (2005) provides an overview of financial literacy questions in several countries. While providing very useful information, it is not possible to perform international comparisons as the questions differ a lot across countries.

Measurement error issues. Despite best efforts, any measure of financial literacy is likely to be affected by measurement error. On the one hand, people may simply guess the answers at 
random, and on the other hand, people may misunderstand question, especially when they listen to questions over the telephone. To evaluate these potential problems, we inverted the question wording in some cases, randomly asking two groups of respondents the same question but with inverted wording. For example when asking about risk diversification, we asked half the group using format (a) and the other half format (b):

(a) Buying a company stock usually provides a safer return than a stock mutual fund. True or false?

(b) Buying a stock mutual fund usually provides a safer return than a company stock. True or false?

We learned that the answers do appear sensitive to how the question is worded in both the U.S. American Life Panel (Lusardi and Mitchell, 2007b) and the Dutch DNB Household Survey (DHS) (Van Rooij, Lusardi and Alessie, 2011). For example, in the DHS, few people answer correctly when the question is whether "buying a stock mutual fund usually provides a safer return than a company stock;” correct responses double the same question is asked in inverted order: "buying a company stock usually provides a safer return than a stock mutual fund.” This is not simply due to people using a crude rule of thumb such as always picking the first option as correct, since this would lead to a lower rather than higher percentage of correct answers for version (a). In other words, some respondents do not understand the questions and do not know what stocks, bonds, and mutual funds are. Accordingly some correct answers are the result of guessing, implying that empirical analysis to the advanced financial literacy questions should take into account that these measures can be noisy proxies of true financial knowledge levels.

\section{Does financial literacy matter?}


Of course ultimately we seek to learn not just how much people know, but also how financial literacy matters over the life cycle. Intertemporal economic choice models posit that people formulate assumptions about their lifetime resources and make consumption decisions on those anticipated resources, rather than simply based on current income. Some degree of forward-looking perspective is required, so that people can save to smooth consumption over their lifetime. Yet implementing such life cycle model would require taking a stand on a host of assumptions about preferences and risk aversion as well as discount rates, expectations about lifetime income streams and capital market returns, borrowing possibilities, and income shocks (Chai et al. 2010), most of which are not particularly easily measured in empirical data. ${ }^{3}$ Accordingly, rather than imposing specific preferences and constraint structures, we instead focus on a behavioral outcome consistent with life-cycle behavior, namely whether people plan for retirement.

Several prior studies have shown that people who plan for retirement do, in fact, accumulate more retirement saving. For instance Lusardi (1999) showed that a 1992 HRS question asking people how much they thought about retirement (a lot, some, a little or hardly at all) was a strong predictor of retirement wealth. In addition, the impact was quantitatively important for the HRS respondents in their mid-50s: those who thought about retirement had double the wealth of those who had not thought about retirement. Similar findings were measured in the 2004 HRS (Lusardi and Beeler, 2007). A different question in the 2004 HRS experimental module asked whether people had even tried to calculate how much they needed to

\footnotetext{
${ }^{3}$ Even if people are not financially literate, they might consult others in making financial decision so their own knowledge might not matter. Similarly, some people could make good financial decisions because there are simple rules of thumb that could approximate optimal financial behavior. For instance, Deaton (1992) showed that optimal outcomes from a very complex model of saving under uncertainty with liquidity constraints could be approximated by simple saving rules, such as saving a certain percent of income above a certain subsistence level. Ongoing research is attempting to differentiate between these different approaches to saving behavior.
} 
save for their retirement to measure planning (Lusardi and Mitchell, 2011). This question has also been used in the Retirement Confidence Survey (Yakoboski and Dickemper, 1997) as a means of assessing whether individuals are forward-looking and attempt to calculate how much they need to save as the life cycle model implies. Results showed that those who planned for retirement accumulated three times as much wealth as those who did not (Lusardi and Mitchell, 2011). Planning has also been associated with higher wealth even among the better educated (Ameriks et al. 2003). It is also of interest that planning is important for the young and middle aged, as shown in the American Life Panel (Lusardi and Mitchell, 2009). Moreover, the nexus of causality goes from retirement planning to wealth, and not the other way around (Lusardi and Mitchell, 2009; Lusardi and Mitchell, 2007a).

The next question is why people fail to plan, and we argue that a key reason is because they are financially unsophisticated. Obviously planning requires making calculations, many of which are facilitated by financial literacy. For example, less sophisticated individuals who do not have a good grasp of interest compounding may engage in high-cost credit-card borrowing, or they may be more likely to pay high fees when using financial services. Lusardi and Tufano (2009) found that low literacy individuals are more likely to carry high-cost debt and to have problems with debt. More financially literate individuals tend to include stocks in their portfolios, as they better understand the principle of risk diversification (Van Rooij et al. 2011; Christelis et al. 2010). There are also other channels via which financial literacy operates. For example higher literacy individuals may be more likely to choose funds with lower fees or be more savvy about fund expenses; for instance there is a strong correlation between financial literacy and investment in lower cost funds (Hastings and Tejeda-Ashton, 2008; Hastings et al. 2010; Hastings and Mitchell, 2011). 
All in all, what this review suggests is that there is a potentially important role of financial literacy in shaping retirement planning. How strong this relationship is an empirical question and the evidence across eight countries can teach us about this important relationship.

\section{Financial literacy around the world}

In collaboration with several other teams from a wide range of countries, we have started to explore how the 2004 module HRS financial literacy questions work in the international context, as well as how they relate to patterns of retirement planning. ${ }^{4}$ Results are reported in more detail in the remainder of this volume; here we outline several key lessons. First, financial illiteracy is widespread even when financial markets are well developed as in Germany, the Netherlands, Sweden, Italy, Japan, and New Zealand. Thus observed low levels of financial literacy in the U.S. are prevalent elsewhere, rather than specific to any given country or stage of economic development. Second, there are notable differences across countries. For example, where people score high on math and science tests, they also tend to score high also on questions measuring numeracy. As examples, respondents in Sweden and the Netherlands do well on math tests (e.g. the Programme for International Student Assessment; OECD, 2005) and they also score high on numeracy. Third, people are more knowledgeable about inflation if their country has experienced it recently. For example, Italians are more likely to answer the question on inflation correctly. Conversely, in a country like Japan that experienced deflation, many fewer people answer the inflation question correctly. Fourth, people are more knowledgeable about risk

\footnotetext{
${ }^{4}$ We first piloted these questions using the Dutch Central Bank Household Survey (DHS) and we showed that these questions seem well adapted (van Rooij, Lusardi and Alessie, 2011). Several countries have also undertaken to measure "financial capability," which is meant to focus not only on financial knowledge but also on ability to undertake particular financial behaviors. The United Kingdom was among the first to field a survey on financial capability in 2005, and related efforts were undertaken in New Zealand, Australia, Ireland, Canada, and the Netherlands (Atkinson et al. 2006, 2007).
} 
diversification if the country recently experience pension privatization, as in Sweden. By contrast, Russians and people born in East Germany know less about risk diversification. It is notable, however, that even in countries with very developed financial markets, many respondents state they do not know about risk diversification; for example in the U.S, as many as one-third of respondents say they do not know how to answer the risk diversification question.

The studies in this international project also indicate that financial literacy differs by population subgroup. Age patterns are notable, in that financial knowledge follows an inverted U-shaped pattern, being lowest for the young and the older groups, but peaks in the middle of the life cycle. In a single cross-section we cannot distinguish between age and cohort effects, but we hypothesize that the pattern is consistent with knowledge rising with experience and decaying at older ages.

Another remarkable finding has to do with persistent international sex differences in financial literacy: in most cases, women are less financially knowledge than are men. ${ }^{5}$ Moreover, women are not only less likely to answer the questions correctly, but they are more likely to state they do not know the answers, compared to men. This is a systematic and persistent difference between men and women in financial literacy. In Russia and for residents of East Germany, there are no sex differences in financial knowledge - and both women and men are equally financial illiterate. But when comparing East versus West Germans, those living in the West are most financially knowledgeable, and financial knowledge in the West is sharply worse for women than for men. Thus it seems that women have more difficulty catching up with economic and financial market development, than do men.

In all countries, higher educational attainment is strongly correlated with financial knowledge, but even at the highest level of schooling, financial literacy tends to be low.

\footnotetext{
${ }^{5}$ This confirms US findings in Lusardi and Mitchell (2008a).
} 
Moreover, education is not a good proxy for financial literacy. That is, when education and financial literacy are included in multivariate regression models, both tend to be statistically significant, indicating that financial literacy has an effect above and beyond education. Financial literacy is also higher among those who are working, and in some countries among the selfemployed, compared to those who do not work. This difference may in part result from financial education programs offered in the workplace (as in the United States); it could also be the effect of learning from colleagues or skills acquired on the job.

Some countries report interesting patterns along other dimensions. For example, in the U.S., there are large racial/ethnic differences in financial knowledge: Whites and Asians are consistently more likely to be financially knowledgeable compared to African Americans and Hispanics. Moreover, there are large geographic differences in financial literacy. For instance, financial literacy in Italy is higher in the Northern and Central regions than the Southern regions, though not all of the Northern regions show high levels of financial knowledge. There are also urban/rural differences: people living in urban areas in Russia tend to be more financially literate than those living in rural areas. This is may well be due to differential exposure to the modern financial sector in the last few decades. There are also notable differences in financial knowledge among people with different religious beliefs; in the Netherlands, those of other religion (which includes Muslims and other smaller religious groups) are less likely to be financially knowledgeable.

Not only are there interesting patterns in measured financial literacy, but we also can compare what people actually know with their self-assessed financial literacy. Across countries we tend to see that younger people know very little and acknowledge it. By contrast, older people consistently rate themselves as very knowledgeable despite the fact that they are actually 
less literate than average. There are also important international differences in self-reports: in the U.S., for instance, a majority of respondents gives themselves high scores, whereas in Japan people score themselves quite low.

The international studies of financial literacy also explore how financial literacy relates to retirement planning. In the majority of the countries studied, those who are more financially literate are more likely to plan for retirement, even after accounting for a large set of economic characteristics and economic circumstances. Given the many differences in pension schemes, privatization of pensions, and generosity of the pension system across countries, this is a remarkably consistent result. While some may argue that financial literacy is itself a choice variable so that the association between financial literacy and retirement planning may not be causal, the studies reported herein find little evidence that people invest much in financial knowledge. Indeed, it is unclear how people could improve their financial knowledge even if they wished to, given the paucity of adult education programs in several of the countries reviewed here.

In addition, the country studies also allow the authors to control for unobservable factors that would otherwise make results difficult to interpret in terms of causation. For example, in the Netherlands, information about financial literacy and retirement planning was collected at two different time periods, with the panel feature of the data permitting the analysts to control for unobservables such as cognitive skills, intelligence, or interest in financial matters. In some cases researchers can also examine whether financial literacy at one point is correlated with retirement planning at some future point. More generally, the nexus of causality can be explored with an instrumental variables (IV) approach, to examine whether exogenous factors correlated with financial literacy but uncorrelated with retirement planning can shed light on the relationship 
between these factors. (IV is also useful when financial literacy is measured with error, as noted above). Several different IV approaches are used. One is to assert that a respondent might not be in a position to influence the behavior of others. In the Netherlands, for example, we find that people whose oldest siblings are in worse financial condition than the respondent's and whose parents have low understanding of financial matters are more likely to display high financial literacy. In Germany, the fraction of people voting for market-oriented parties is used to proxy for having well-informed peers. Here the results indicate that those having more informed peers are more likely to have higher financial knowledge.

Last, but certainly not least, the conclusions from the country studies examined herein show that financial literacy is an important predictor of retirement planning, for both instrumented and non-instrumented empirical models. Answering one additional financial question correctly is associated with a 3 to 4 percentage point higher probability to plan for retirement in countries as diverse as Germany, the United States, Japan and Sweden. The effect of literacy is highest in the Netherland, where answering an additional financial literacy question is associated with a 10 percentage point higher probability of planning for retirement. Thus, around the world, we uncover the same finding, financial literacy makes people plan more enabling them to be more financially secure in their retirement.

\section{Concluding remarks}

Fielding the same questions to measure financial knowledge across eight countries has provided a deeper understanding of the causes and consequences of financial illiteracy. We conclude that financial literacy is very low around the world, irrespective of the level of financial market development and the type of pension provided. Accordingly, changes in markets have 
apparently not wrought enhancements in financial knowledge, suggesting that there may be a limit on what people can learn by themselves from their financial experience. There are also important sex and age differences common across countries in financial knowledge. Women uniformly know less, and they know they know less, than do men, in terms of financial knowledge. Low levels of financial knowledge in older populations also suggest that these groups may be particularly vulnerable.

Third, most workers, including older ones, have not planned or even thought much about retirement. This is important because retirement planning is a good proxy for retirement wealth; those who have calculated how much they need to save for their own retirement reach retirement age with three times the wealth of those who did no such calculations. We also show that retirement planning can be traced back to financial literacy; those can accurately undertake simple calculations, know about inflation, and are knowledgeable about risk diversification, are all more likely to plan for their retirement. Finally, we argue that this relationship is causal: that is, financial literacy influences retirement planning, and not the other way around.

Fourth, it seems clear now that financial literacy should not be taken from granted, even in countries with very developed financial markets. Indeed as the long-term shift continues toward individual responsibility for retirement saving, investment, and decumulation, it is important to evaluate which programs can best help people make good financial decisions. And last, to be effective, financial education programs will be most effective if targeted to different population subgroups. In sum, around the world, financial literacy is critical to retirement security. 


\section{References}

Ameriks, John, Andrew Caplin, and John Leahy. (2003). "Wealth Accumulation and the Propensity to Plan.” Quarterly Journal of Economics 68, 1007-1047.

Atkinson, Adele, Stephen McKay, Elaine Kempson, and Sharon Collard. (2006). "Levels of Financial Capability in the UK: Results of a baseline survey." UK: Financial Services Authority.

Atkinson, Adele, Stephen McKay, Elaine Kempson, and Sharon Collard. (2007). "Levels of Financial Capability in the UK: Results of a Baseline Survey," Public Money \& Management, 27(1): 29-36, February.

Banks, James and Zoe Oldfied. (2007), "Understanding Pensions: Cognitive Functions, Numerical Ability and Retirement Saving,” Fiscal Studies, 28(2).

Behrman, Jere, Olivia S. Mitchell, Cindy Soo, and David Bravo. (2010). "Financial Literacy, Schooling, and Wealth Accumulation.” NBER WP 16452.

Bernheim, Douglas. (1995). "Do Households Appreciate their Financial Vulnerabilities? An Analysis of Actions, Perceptions, and Public Policy.” In Tax Policy and Economic Growth, American Council for Capital Formation, Washington, DC, pp. 1-30.

Bernheim, Douglas. (1998). “Financial Illiteracy, Education and Retirement Saving,” in O.S. Mitchell and S. Schieber (eds.), Living with Defined Contribution Pensions, University of Pennsylvania Press, Philadelphia, pp. 38-68.

Chai, Jingjing, Wolfram Horneff, Raimond Maurer, and Olivia S. Mitchell. (2010). "Extending Life Cycle Models of Optimal Portfolio Choice: Integrating Flexible Work, Endogenous Retirement, and Investment Decisions with Lifetime Payouts.” NBER WP 15682 January.

Christelis, Dimitris, Tullio Jappelli, and Mario Padula. (2010). “Cognitive Abilities and Portfolio Choice,” European Economic Review 54, pp. 18-38.

Financial Industry Regulatory Authority. (FINRA; 2010). Financial Capability in the United States: National Survey, Executive Summary. Washington, D.C. http://www.finrafoundation.org/resources/research/p120478

Hastings, Justine and Olivia S. Mitchell. (2011). “How Financial Literacy and Impatience Shape Retirement Wealth and Investment Behaviors.” NBER Working Paper No. 16740.

Hastings, Justine, Olivia S. Mitchell, and Eric Chyn. (2010). “Fees, Framing, and Financial Literacy in the Choice of Pension Managers.” Pension Research Council Working Paper, Wharton School. Summer.

Hastings, Justine, and Lydia Tejeda-Ashton (2008), "Financial Literacy, Information, and Demand Elasticity: Survey and Experimental Evidence from Mexico,” NBER Working Paper No. 14538.

Hilgert, Marianne, Jeanne Hogarth, and Sondra Beverly (2003), "Household Financial Management: The Connection between Knowledge and Behavior,” Federal Reserve Bulletin, 309-32.

Lusardi, Annamaria (1999), “Information, Expectations, and Savings for Retirement,” in Henry 
Aaron (ed.), Behavioral Dimensions of Retirement Economics, Washington, D.C.: Brookings Institution Press and Russell Sage Foundation, pp. 81-115.

Lusardi, Annamaria. (2009). "U.S. Household Savings Behavior: The Role of Financial Literacy, Information and Financial Education Programs,” in C. Foote, L Goette, and S. Meier (eds), Policymaking Insights from Behavioral Economics, Federal Reserve Bank of Boston, pp. 109-149.

Lusardi, Annamaria. (2010). Americans’ Financial Capability. Report for the Financial Crisis Inquiry Commission. Washington, DC. February.

Lusardi, Annamaria and Jason Beeler. (2007). "Saving Between Cohorts: The Role of Planning," in B. Madrian, O. Mitchell, and B. Soldo (eds.), Redefining Retirement: How Will Boomers Fare? Oxford University Press, Oxford: 271-295.

Lusardi, Annamaria, and Olivia S. Mitchell. (2007a), "Baby Boomer Retirement Security: The Role of Planning, Financial Literacy, and Housing Wealth,” Journal of Monetary Economics 54, pp. 205-224.

Lusardi, Annamaria and Olivia S. Mitchell. (2007b). "Financial Literacy and Retirement Planning: New Evidence from the Rand American Life Panel.” Pension Research Council Working Paper WP2007-3.

Lusardi, Annamaria, and S. Olivia Mitchell. (2007c). "Financial Literacy and Retirement Preparedness: Evidence and Implications for Financial Education,” Business Economics, January 2007, pp. 35-44.

Lusardi, Annamaria, and Olivia S. Mitchell. (2008a). "Planning and Financial Literacy. How Do Women Fare?” American Economic Review, 98(2), pp. 413-417.

Lusardi, Annamaria, and Olivia Mitchell. (2008b), "How Much Do People Know About Economics and Finance? Financial Illiteracy and the Importance of Financial Education," Policy Brief n. 5, MRRC, March.

Lusardi, Annamaria and Olivia S. Mitchell. (2009). "How Ordinary Consumers Make Complex Economic Decisions: Financial Literacy and Retirement Readiness.” NBER Working Paper 15350

Lusardi, Annamaria, and Olivia S. Mitchell. (2011) "Financial Literacy and Planning: Implications for Retirement Wellbeing," In Financial Literacy: Implications for Retirement Security and the Financial Marketplace. Eds A Lusardi and O.S. Mitchell . Oxford: Oxford University Press forthcoming.

Lusardi, Annamaria, Olivia S. Mitchell, and Vilsa Curto. (2009). "Financial Literacy and Financial Sophistication among Older Americans.” NBER Working Paper 15469.

Lusardi, Annamaria, Olivia S. Mitchell, and Vilsa Curto. (2010) “Financial Literacy Among the Young,” Journal of Consumer Affairs. 44(2), pp 358-380.

Lusardi, Annamaria, and Peter Tufano. (2009.) "Debt Literacy, Financial Experiences, and Overindebtedness,” NBER Working Paper n. 14808.

Mitchell, Olivia S. (2011). "Managing Risks in Defined Contribution Plans: What Does the Future Hold?” In Growing Old: Paying for Retirement and Institutional Money 
Management After the Financial Crisis. Eds. Yasuyuki Fuchita, Richard J. Herring and Robert E. Litan. Brookings Institution Press and Nomura Institute of Capital Markets Research. Forthcoming.

Moore, Danna (2003), "Survey of Financial Literacy in Washington State: Knowledge, Behavior, Attitudes, and Experiences,” Technical Report n. 03-39, Social and Economic Sciences Research Center, Washington State University.

National Council on Economic Education (NCEE; 2005). What American Teens and Adults Know about Economics. NCEE: Washington, D.C.

Organization for Economic Co-operation and Development (OECD; 2005), Improving Financial Literacy: Analysis of Issues and Policies. OECD: Paris, France.

Poterba, James, Steve Venti, and David Wise (2008), “The Changing Landscape of Pensions in The United States." In Overcoming the Saving Slump: How to Increase the Effectiveness of Financial Education and Saving Programs. Ed. A Lusardi. Chicago: University of Chicago Press: 17-46.

van Rooij, Maarten, Annamaria Lusardi, and Rob Alessie. (2011). "Financial Literacy and Stock Market Participation.” Journal of Financial Economics forthcoming.

Yakoboski, Paul and Jennifer Dickemper. (1997). "Increased Saving but Little Planning: Results of the 1997 Retirement Confidence Survey,” EBRI Issue Brief, 191. 